\title{
Métodos pioneiros de ensino musical no Brasil: críticas, lutas e rivalidades
}

\author{
Pioneering Music Teaching Methods in Brazil: Criticism, Contest and Rivalries
}

\author{
Ailton Pereira Morila \\ Universidade Federal do Espírito Santo, São Mateus, Espírito Santo, Brasil \\ Aiton.morila@ufes.br
}

Resumo: No final do século XIX e início do século XX, transformações políticas e sociais marcaram o Brasil: abolição, imigração, República, reformas urbanas. Um dos motes destas reformas era a educação. A educação elevaria o Brasil à nação civilizada. Na educação, a música se apresentava como importante e até essencial. O ensino musical tornou-se preocupação de músicos e educadores. No estado de São Paulo, vários métodos foram criados. A cada método inúmeras críticas e discussões se seguiam. 0 objetivo deste artigo é trazer a tona alguns destes métodos pioneiros bem como as críticas, lutas e rivalidades em torno deles, que denunciam não somente uma questão educacional, mas uma luta por espaços sociais, notadamente na cultura escolar, erudita e popular.

Palavras-chave: educação musical no Brasil República (século XIX e XX); métodos de ensino musical; cultura escolar erudita e popular.

Abstract: In the late nineteenth and early twentieth centuries, political and social transformations marked Brazil: abolition, immigration, Republic, urban reforms. One of the themes of these reforms was education. Education would elevate Brazil to a civilized nation. In education, music was presented as important and even essential. Music teaching became a concern for musicians and educators. In São Paulo, several methods have been created. Much criticism and discussions followed every emerging method. The purpose of this article is to bring to light some of these pioneering methods as well the criticism, contests and rivalries around them which voiced not only a matter of education, but a contest for social spaces, especially in the educational, scholarly and popular culture.

Keywords: Music Education in Republican Brazil (nineteenth and twentieth centuries); musical teaching methods; scholarly and popular culture in education.

Data de recebimento: 03/12/2015.

Data de aprovação final: 29/03/2016. 


\section{1 - Introdução}

De todos os programmas dos diversos estabelecimentos de educação faz parte o ensino primario da musica e é este o que mais serios cuidados deve merecer do Governo, attenta a insufficiencia da maoria dos compendios adoptados e a opinião controversa dos professores. Leopoldo Miguez, 1891. ${ }^{1}$

No início do período republicano no Brasil parecia haver um consenso: a educação musical era importante para o desenvolvimento do país. A música sintetizaria "o grao de cultura de um povo, a força moral de um Estado" (A Música para todos, 1897, p.200-201). Mas o consenso não ia muito mais longe do que isto. Como educar musicalmente, fora e dentro da escola, foi uma questão polêmica como demonstra Leopoldo Miguez na epígrafe, então diretor do Instituto Nacional de Música do Rio de Janeiro.

No estado de São Paulo, vários métodos foram criados. Outros foram importados. A cada método utilizado ou criado inúmeras críticas se seguiam. Para além destes métodos os músicos populares aprendiam assistematicamente em um método da rua, aquecendo ainda mais as discussões. 0 objetivo deste artigo é trazer a tona alguns destes métodos pioneiros bem como as críticas, lutas e rivalidades em torno deles, que denunciam não somente uma questão educacional, mas uma luta por espaços sociais, notadamente na cultura erudita e na cultura escolar.

\section{2 - Denunciando o problema}

Em artigo intitulado “o ensino de música nas escolas públicas”, publicado n’A Música para todos em 1898, o autor, que não se identificou, mas que o jornal diz ser "pessoa competente" critica o ensino de música nas escolas. Apesar de ser um estudo de muitos anos, os alunos saiam despreparados. Não para aí a crítica deste artigo. Os coros escritos para as festas escolares eram, segundo ele, de péssima qualidade. Habaneiras em versos impróprios, fugattos descompassados com a poesia,

\footnotetext{
${ }^{1}$ No presente artigo, mantém-se a grafia antiga do português em citações como em "ensino primario da musica".
} 
MORILA, Ailton Pereira (2016). Métodos pioneiros de ensino musical no Brasil: críticas, lutas e rivalidades. Per Musi. Ed. por Fausto Borém, Eduardo Rosse e Débora Borburema. Belo Horizonte: UFMG, n.34, p.1-34.

composições que não se preocupam com a idade dos integrantes do coro e assim por diante. Como uma possibilidade de solução, o autor propõe trazerem da França, Alemanha e Itália coros escritos por pessoas competentes, incentivando assim que os compositores locais se esforcem para produzir coros de melhor nível. A questão é assim posta: enquanto que nestes países existe uma preocupação com a composição específica para a escola, ou em outras palavras, há especialistas neste gênero de composição, no Brasil segundo o autor “Tutti quanti escrevem!”. Enfim, o autor sugere:

\begin{abstract}
Cremos que os coros para as escolas modelos, devem ser muito simples, quase populares, porque se trata geralmente de alunos de tenra idade; os da escola normal ao contrário, devem ser mais sérios, não no estilo fugato, quando a letra não comporta, porém no gênero mais variado: - a duas, tres e mesmo quatro partes. Convém que se de uma instrução sólida a esses alunos, banindo as composições de pessoas incompetentes; representando mesmo ao governo nesse sentido, pedindo para que as composições que tenham de ser exibidas nessas escolas, sejam aprovadas por uma comissão especial, a fim de evitar-se o descalabro, como tive ocasião presenciar numa das festas últimas. (A Música para todos, 1898, p.452)
\end{abstract}

Uma boa orientação, uma seleção e uma comissão especial seriam instrumentos para a melhoria da qualidade.

Outro artigo, de 1899, escrito com o pseudônimo de "colombat", retoma a crítica, agora voltada para o ensino de canto. Não somente o canto escolar, mas também fora da escola. Logo no início do artigo, o autor dispara: "Quem é que não ensina canto n'esta cidade? Basta mandar abrir a boca e gritar, eis o que é necessário! Quantas vozes arruinadas pela incapacidade do professor!” (A Música para todos, 1899, p.538). Alertando os pais e o público em geral para os malefícios de um ensino de péssima qualidade, o autor chama os professores de charlatães e aponta até mesmo as doenças que podem advir deste ensino: rouquidão, inflamações da laringe e faringe entre outras.

Se a crítica é similar ao artigo anterior, a solução também é próxima. Primeiro, o professor deve ter um conhecimento científico prévio: ter "o conhecimento exato do complicado mecanismo deste órgão mysterioso", saber o funcionamento do nariz, 
MORILA, Ailton Pereira (2016). Métodos pioneiros de ensino musical no Brasil: críticas, lutas e rivalidades. Per Musi. Ed. por Fausto Borém, Eduardo Rosse e Débora Borburema. Belo Horizonte: UFMG, n.34, p.1-34.

garganta seria a garantia para se evitar excessos. Aliado ao conhecimento científico prévio, os professores deveriam preocupar-se com "a importante questão da interpretação", pois o ensino é feito "sem o menor escrúpulo, sendo desprezadas as leis da prosódia, o conhecimento da língua, da situação e do sentimento que se deve exprimir". Completando, o autor propõe algumas regras básicas a serem seguidas:

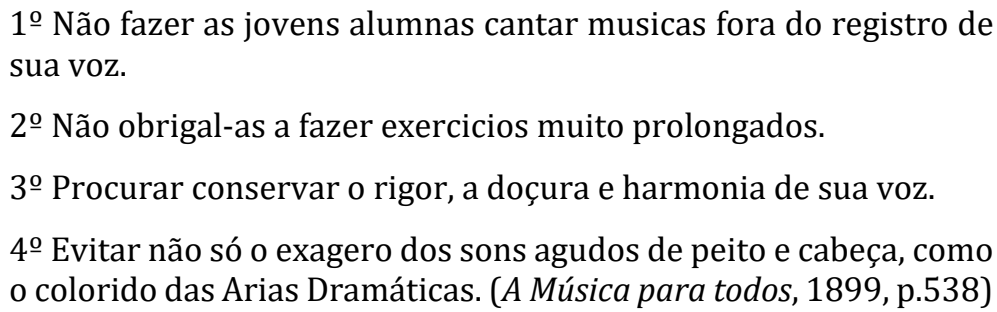

No primeiro artigo, da mesma maneira, o autor recorreu a algumas regras básicas para o ensino de música. Se o ensino de música, o canto coral e o ensino de música vocal são permeados por um "falta de método, e falta de uma orientação segura" a solução seria:

\footnotetext{
É chamar o digno professor da escola normal, moço preparado, combinar com ele e auxílio de mais professores desta capital, qual o meio que se deva seguir, porque assim ficará estabelecido o ensino regular, adotando-se um só compêndio para todas as escolas... (A Música para todos, 1898, p.452)
}

A adoção de um método único por todas as escolas, método este referendado pelos professores de música da cidade, e baseado nas regras científicas de então era a solução proposta por estes dois artigos.

Entretanto, na época em que estes dois textos foram escritos (1898 e 1899), já existiam métodos de ensino musical. E críticas. A cada método que surgia com a pretensão de ser o único, a crítica se fazia presente e a polêmica se acentuava.

\section{3 - Primeiros métodos em São Paulo}

A primeira sugestão conhecida de se criar um método único para a educação musical em São Paulo, parte de Elias Alvares Lobo, por ocasião da frustrada iniciativa de se criar uma associação musical no estado em 1875. Uma das pautas do congresso 
MORILA, Ailton Pereira (2016). Métodos pioneiros de ensino musical no Brasil: críticas, lutas e rivalidades. Per Musi. Ed. por Fausto Borém, Eduardo Rosse e Débora Borburema. Belo Horizonte: UFMG, n.34, p.1-34.

realizado na capital era: "Apresentarmos nossos methodos de ensino, discutirmos e adoptarmos o melhor." (citado por SERGL, 1991, p.237)

Proposta não realizada, ao que parece. No ano seguinte, Tristão Mariano da Costa, um dos organizadores do congresso, ainda exultava os músicos a unificarem os seus métodos, pois:

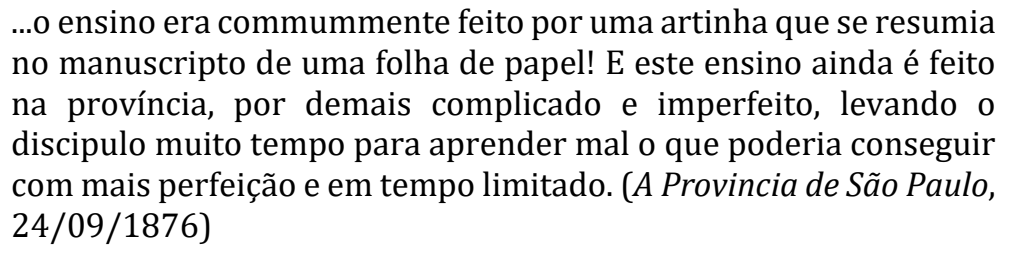

Tristão Mariano da Costa utilizava, entretanto, um método musical com seus alunos desde 1870. Tratava-se do $A B C$ musical de Raphael Coelho Machado, músico português radicado no Rio de Janeiro. Apesar da existência e utilização deste método, ele afirma que poucos o conheciam, e talvez por isso se utilizassem de "um manuscripto de uma folha de papel": "Até bem pouco tempo o $A B C$ musical do grande Raphael Coelho Machado, a melhor arte actualmente para o ensino primário da musica era desconhecido entre nós..." (A Provincia de São Paulo, 24/09/1876). Mas se em 1876, este método era pouco conhecido, este cenário deve ter se modificado, pois esta obra contou com pelo menos 40 edições.

Voltando ao congresso e aos apelos de Elias Alvares Lobo e Tristão Mariano da Costa, frustrou-se a expectativa de se criar um método único referendado por todos os professores. Elias Alvares Lobo parece, no entanto, ter chamado a tarefa para si, pois em 1875 terminou seu Methodo de Musica, em Bethlem de Jundiahy. (SERGL, 1991, p.242)

Outra possibilidade é que o método de Elias Alvares Lobo já havia sido escrito e a idéia era referendá-lo no congresso, o que acabou não acontecendo. Esta hipótese, reforçada pelo fato de que Elias Alvares Lobo e seu cunhado Tristão Mariano da Costa tenham organizado o congresso e colocado na pauta de discussões a questão do método, é verossímil, apesar de ser de difícil confirmação. 
MORILA, Ailton Pereira (2016). Métodos pioneiros de ensino musical no Brasil: críticas, lutas e rivalidades. Per Musi. Ed. por Fausto Borém, Eduardo Rosse e Débora Borburema. Belo Horizonte: UFMG, n.34, p.1-34.

0 Methodo de musica ${ }^{2}$ teve a sua primeira edição em 1877, e a segunda edição em 1881. Em 1896, uma terceira edição estava à disposição, provavelmente em decorrência de ter sido aprovado pelo Conselho Superior de Instrução Pública do Estado de São Paulo no ano anterior, para uso das escolas públicas de São Paulo. (SERGL, 1991, p.245-246)

Elias Alvares Lobo teria ainda outra obra publicada e aprovada pelo Conselho Superior de Instrução Pública, a Arte da Musica em diálogo - específica para crianças - obra que segundo SERGL (1991, p.247) se perdeu. Esta obra teve a aprovação de Raphael Coelho Machado em carta publicada n'A Provincia de São Paulo $(11 / 11 / 1876)$.

Apesar da aprovação de Raphael Coelho Machado, aliás professor de Elias Alvares Lobo, e da afirmação de SERGL (1991, p.242) dizendo que o método "se tornou grandemente aceito pelos músicos paulistas”, o método sofreu críticas severas.

As críticas vieram após a aprovação pelo Conselho Superior de Instrução Pública do Estado de São Paulo, quando o Methodo de musica contava com sua terceira edição. O primeiro a manifestar-se sobre a Arte da musica em diálogo é A.Karr., em artigo n'A Paulicéia:

\footnotetext{
A forma de exposição usada pelo velho professor é o diálogo, e não nos parece ser esta a forma mais adequada ao ensino.

Pode-se dizer que o diálogo está varrido de todos os livros didacticos. É melhor deixar a cargo e a juízo de professor as perguntas que tiver que fazer, fornecendo apenas o livro a substancia para as respostas. (A Paulicéia, 1896 n.34, p.7)
}

Com relação ao Methodo de musica, o autor apesar de confessar-se não entendedor de música, dispara críticas à orientação pedagógica, pois ao invés de fornecer "idéias perfeitas e exactas", o livro se perde em comparações complicadas. A linguagem também elucida a posição do autor com relação a obra de Elias Alvares Lobo: agradece o recebimento do "livrinho", e se refere ao autor com "velho professor" que utiliza um velho método.

\footnotetext{
${ }^{2}$ Uma análise do método pode ser vista em MORILA (2004).
} 
MORILA, Ailton Pereira (2016). Métodos pioneiros de ensino musical no Brasil: críticas, lutas e rivalidades. Per Musi. Ed. por Fausto Borém, Eduardo Rosse e Débora Borburema. Belo Horizonte: UFMG, n.34, p.1-34.

Não para por aí a crítica no periódico. No número 35, aparece outra manifestação, que inicia chamando a obra de "compendiosito de musica, que é ao mesmo tempo uma pequena encyclopédia do riso e da galhofa". Exagerando na ironia, continua o autor, agradecendo por Carlos Gomes achar-se morto e não ter o desprazer de ler o que o amigo Elias Alvares Lobo escrevera. Elias Alvares Lobo é alvo de crítica justamente naquilo que estava convencido tratar-se de uma inovação, a simplificação das definições. Assim, a definição "o compasso é a medida exacta do tempo" é ridicularizada nos seguintes termos:

\begin{abstract}
Até aqui todos julgávamos que a medida do tempo se obtinha pelos movimentos da terra; teremos de reformar o calendário e introduzir o compasso, como novíssimo regulador. E esta descoberta do Kepler musical nada é, em comparação com muitas outras do seu livrinho. (A Paulicéia, 1896 n.35, p.7-8)
\end{abstract}

Se no artigo anterior a metodologia e o seu autor eram criticados como velhos e atrasados, agora o são as definições por serem simplórias e por não corresponderem à verdades científicas, como esperaria o autor do artigo. Em carta enviada ao periódico A Música para todos, um assinante (A.P.S.) explica que é um amante da música e que procura ensinar os seus filhos em sua própria casa e por sua conta, visto não dispor de recursos suficientes para mandar seus filhos a uma escola especializada. Dentro deste contexto, diz interessar-se por qualquer obra didática em português, o que o levou a compra da Arte da música em diálogo de Elias Alvares Lobo. 0 leitor se mostra admirado, tanto com o autor da obra quanto pela "boa fé" do Conselho Superior de Instrução Pública do estado de São Paulo em aprová-la. De lição em lição, vai expondo as contradições, as comparações pouco explicativas, a ponto de descrever a obra como a "artinha de Elias Alvares Lobo" (A Música para todos, 1897, p.179-181), aproximando-a, com essa designação, dos compêndios adotados nos colégios jesuítas do período colonial.

Antes dos métodos de Elias Alvares Lobo serem aprovados pelo Conselho de Instrução Pública - e surgirem críticas na esteira da aprovação - os métodos utilizados nas escolas eram adaptações de consagrados métodos utilizados no exterior. Gabriel Prestes (1895, p.138), em seu Relatório da Escola Normal escreve 
MORILA, Ailton Pereira (2016). Métodos pioneiros de ensino musical no Brasil: críticas, lutas e rivalidades. Per Musi. Ed. por Fausto Borém, Eduardo Rosse e Débora Borburema. Belo Horizonte: UFMG, n.34, p.1-34.

que na Escola Normal "Caetano de Campos" era utilizado o método Gallin-ParisChevé.

0 método Gallin-Paris-Chevé surgiu na França em 1817, por obra de Pierre Gallin. Foi posteriormente modificado por um seu discípulo (Aimé Paris), sua irmã (Nanine Chevé), e o marido desta (Emil Chevé) tendo como fonte de inspiração Rousseau. Gallin chamava seu método de meloplasto. Depois das modificações passou a ser conhecido como método modal Rousseau-Galin-Paris-Chevé ou simplesmente Gallin-Paris-Chevé3.

Segundo GILIOLI (2003), o método foi trazido ao Brasil por João Gomes Jr. Entretanto não há indícios que corroborem esta afirmação. Ao contrário, Gabriel Prestes, então diretor da Escola Normal afirma em seu relatório:

Para o ensino de música, adoptou-se o ano passado [1894, para o segundo ano da Escola Modelo] o systema denominado Galin-ParisChevé, do qual nos offereceu o dr.João Köpke alguns manuais, e colleções de exercícios. (1895, p.138).

Além das próprias palavras de Prestes, devemos levar em conta que, em 1894, João Gomes Jr. ainda não estava na Escola Normal, mas lecionava na Escola Modelo "Prudente de Moraes", ao passo que Köpke era um conhecido educador, vezeiro em novidades pedagógicas, importando materiais do exterior nas suas escolas. De qualquer modo, Köpke e Prestes eram conhecidos e partilhavam do mesmo círculo de relações de longa data (HILSDORF, 1986), reforçando a versão de que seria Köpke o introdutor deste método.

Outro método em voga na Escola Modelo era o "Tonic-solfa", como afirmou PRESTES (1895, p.138): “O ensino de música na escola é iniciado, como já deixei dito, por dous processos: o tonic-solfa e o systema Galin". Semelhante ao método Gallin-ParisChevé, o Tonic-solfa teve seu desenvolvimento na Inglaterra. Enquanto que o método francês transformava as notas em números, “...o método inglês grafa as notas com letras (Dó por d, Ré por $r$, Mi por $m$, etc.), as quais também representam apenas a

\footnotetext{
${ }^{3}$ Para explicação deste método ver GILIOLI (2003).
} 
MORILA, Ailton Pereira (2016). Métodos pioneiros de ensino musical no Brasil: críticas, lutas e rivalidades. Per Musi. Ed. por Fausto Borém, Eduardo Rosse e Débora Borburema. Belo Horizonte: UFMG, n.34, p.1-34.

posição relativa dos sons, isto é, o intervalo entre eles". (GILIOLI, 2003, p.61). A chegada deste método ao Brasil também não está clara. Segundo GILIOLI (2003) foi miss Browne que o adotou nas escolas paulistas. Gomes CARDIM (1926) confirma isto. Entretanto, como Gilioli mesmo afirma, o "Colégio Piracicabano pode ter sido o pioneiro na inovação da pedagogia musical da época" adotando o método Tonicsolfa. Gilioli sustenta a afirmação com base na procedência estadunidense do colégio, e que nos Estados Unidos o tonic-solfa gozava de popularidade (2003, p.86). Provavelmente, como miss Browne era ligada à Escola Americana de São Paulo, e esta e o Colégio Piracicabano eram escolas americanas de confissão protestante com profundas ligações com as lideranças republicanas do período (HILSDORF, 1986), ambas concorreram para fazer circular essa metodologia de ensino musical em São Paulo, no período.

De qualquer maneira, é interessante notar que concorriam dois métodos semelhantes (mas com notações diferentes) nos dois primeiros anos da Escola Modelo. Um deles de origem francesa e outro inglês (largamente utilizado nos EUA). Duas nações consideradas modelos para a reforma pública paulista. Como eram conciliados estes dois métodos não podemos saber, mas podemos inferir a existência de confusões por parte dos alunos. A nota Dó era representada por $d$ ora por 1. A partir do 4ํano - nos explica PRESTES (1895) - a "notação comum", ou seja Dó, era adotada. Antes disso, muito provavelmente o método do português Eduardo MACEDO (1886) intitulado Principios Elementares de música para uso das escolas de ensino primário de um e outro sexo colligidos segundo o programma official foi utilizado, ou pelo menos analisado, pois no arquivo Paulo Bourroul encontra-se a segunda edição do mesmo, com carimbo da Escola Normal.

Portanto, quando a imprensa especializada clamava por uma qualidade maior no ensino musical em 1898 e 1899, o método de Elias Alvares Lobo (aprovado em 1895), o método de Raphael Coelho Machado, o método de Eduardo MACEDO (1886), método Galin-Paris-Chevé e o método Tonic-solfa concorriam para o ensino musical tanto nas escolas públicas quanto para o ensino particular.

No período de dois anos (1894-1895) três métodos lutavam pela primazia de ser o único, procurando substituir os antigos métodos até então em voga. 0 Método de 
MORILA, Ailton Pereira (2016). Métodos pioneiros de ensino musical no Brasil: críticas, lutas e rivalidades. Per Musi. Ed. por Fausto Borém, Eduardo Rosse e Débora Borburema. Belo Horizonte: UFMG, n.34, p.1-34.

Elias Alvares Lobo foi o mais criticado, ou o que mais críticas se publicaram na imprensa especializada. Talvez por ser mais visível - foi publicado no Brasil, enquanto o Tonic-solfa e Galin-Paris-Chevé não - ou talvez porque recaísse sobre ele uma enorme expectativa pois tratava-se do primeiro método aprovado pelo governo republicano, e mais ainda, escrito por um republicano histórico. As inovações no método: novas nomenclaturas, comparações e linguagem simples foram as mais criticadas. 0 tonic-solfa e o Galin-Paris-Chevé não receberam críticas tão efusivas na imprensa - mesmo porque ficaram restritos, ao que tudo indica, ao ambiente escolar. De qualquer maneira, sofreram críticas posteriores, de professores oriundos da própria escola.

Deixemos a escola por um instante e vejamos o que ocorria fora dela.

\section{4 - Um método inovador... e polêmico}

Não foram somente os métodos de Elias Alvares Lobo que causaram polêmica no período. Outro professor, distante do ensino público oficial, enfrentou críticas ao seu método musical. Luigi Chiaffarelli foi uma figura de muita notoriedade na época aliando um "marketing avant la lettre”, como percebeu GONÇALVES (1995, p.186), a uma metodologia aclimatada da Europa, chamou a atenção dos profissionais e dos amadores, arrebatando o público com os concertos que realizava.

A primeira polêmica que vazou para as páginas da imprensa foi entre ele e Felix Otero, então diretor do periódico A Música para todos. Antes de adentrarmos na polêmica, conheçamos um pouco das idéias de Chiaffarelli a respeito da educação musical através de suas obras. A preocupação técnica de Chiaffarelli resultou na publicação do Methodo breve e facil de leitura das notas musicaes especialmente para uso dos pianistas, enquanto a preocupação com um conhecimento musical geral resultou nas Migalhas de educação musical. Com relação à técnica, Chiaffarelli era minucioso. Criticava o "methodo de ensinar a martello" (s/i, p.22) e ilustrava o que isso queria dizer com histórias pitorescas:

Uma menina, muito rosea e muito pacata pergunta à professora de sua irman, que no momento está tocando com phrenesi, para os visinhos da esquina apreciarem, a bençam dos punhaes, no terceiro acto dos Huguenotes: 'Senhora professora, para que serve tocar piano?' - E a professora confusa e zangade: 'Menina, custa pouco ser 
MORILA, Ailton Pereira (2016). Métodos pioneiros de ensino musical no Brasil: críticas, lutas e rivalidades. Per Musi. Ed. por Fausto Borém, Eduardo Rosse e Débora Borburema. Belo Horizonte: UFMG, n.34, p.1-34.

ignorante!' A bôa senhora explicava mais do que ella pensava. Mas é justamente este barulho insupporttavel que afasta a gente dos concertos; é elle que se deve combater: é mesmo áquellas vozes terríveis, discordantes, que saem dos pianos espavoridas que se deve impor silencio.

Duvidar-se-ia da tão apregoada força educativa da musica!

Sua preocupação com a técnica foi analisada exaustivamente por JUNQUEIRA (1982), que além das suas obras utilizou também como fontes as cadernetas de seus alunos. A postura, a posição dos braços e das mãos, a percussão das teclas, a articulação dos dedos, as escalas, os arpejos, os acordes, o ouvido, nada parecia passar desapercebido ao mestre.

Por outro lado, Chiaffarelli acreditava que só a técnica seria insuficiente para formar um músico. Em sua obra Migalhas, em dois volumes, ele demonstra uma preocupação que poderíamos chamar de histórica. Acreditava que suas alunas assim como qualquer músico - deveriam ter um profundo conhecimento não só das obras dos compositores, mas também de suas vidas e da história da música em geral.

Aliado a esta preocupação histórica e a necessidade de suas alunas apresentaremse em público Chiaffarelli organiza, a partir de 1896, uma série de concertos com o título de históricos. Os concertos históricos eram abertos ao público em geral e Chiaffarelli publicava nos jornais os programas destes concertos, além de enviar convites. Mais do que expor suas alunas ao público, Chiaffarelli procurava criar um público. Neste sentido, $O$ Estado de São Paulo parece ter entendido este objetivo dos Concertos Históricos:

\begin{abstract}
Achamos louvável a tentativa do professor Chiaffarelli vulgarizar os conhecimentos sobre a música e os musicos, habilitando o publico a apreciar as tendencias actuaes da grande arte, a conhecer a evolução dos processos, do estylo, das maneiras e de tudo que directa ou indirectamente se prende a musica, deve merecer applausos incondicionaes de professores, de amadores e dos simples curiosos. Para esta vulgarização intelligente muito tem contribuído o professor Chiaffarelli com os seus concertos historicos de musica, se bem que o auditorio destes concertos seja restricto. (O Estado de São Paulo, 6/6/1898, p.1)
\end{abstract}

Apesar de a frequência não ser sempre significativa, com o auditório formado principalmente pelos familiares e amigos das alunas, Chiaffarelli não desanimava. 
MORILA, Ailton Pereira (2016). Métodos pioneiros de ensino musical no Brasil: críticas, lutas e rivalidades. Per Musi. Ed. por Fausto Borém, Eduardo Rosse e Débora Borburema. Belo Horizonte: UFMG, n.34, p.1-34.

Discursando antes e nos intervalos de cada concerto, expunha suas idéias, instava o apoio do governo, exigia maior empenho dos músicos no intuito de criar uma tradição musical na cidade enfim, ministrava uma aula magna não só as suas alunas mas a todo o público presente (JUNQUEIRA, 1982). Foram 60 concertos históricos até 1901, quando passa a realizar "saraus musicaes" que duraram até 1913. (JUNQUEIRA, 1982, p.216-228).

Não é sem razão que Luigi Chiaffarelli ainda hoje é nome lembrado na história do ensino de música em São Paulo. A quantidade de alunos que teve, aliada às suas iniciativas musicais, garantiu a ele um lugar privilegiado na história e na memória musical da cidade.

Mas se houve reconhecimento, tanto hoje quanto na época, não faltaram também críticas. Felix Otero, diretor do periódico A Música para todos publica uma série de críticas à Chiaffarelli. Este por sua vez faz a réplica o que implica em tréplica. Aos dois vem se juntar Gustavo Wertheimer, que também critica Chiaffarelli. Durante todo o ano de 1897 a polêmica se desenrola nas páginas do periódico4. Sem nos preocuparmos com a validade ou não dos argumentos apresentados pelos contendores, uma coisa é certa: o ensino musical em São Paulo, dentro ou fora das escolas, estava longe de um consenso.

\section{5 - 0 método da rua}

Em outro extremo do ensino musical encontramos os músicos populares. Podemos falar em métodos? Como se dava a aprendizagem musical? A música era aprendida assistematicamente no dia-a-dia das classes populares. Este aprendizado musical, comumente chamado de "aprender de ouvido" foi bem descrito em artigo da época. Trata-se do artigo "Musicos amadores", no qual Alfredo Camarate deixa registrado este aprendizado, apesar do objetivo ser bem outro, o de ridicularizar e desabonar este tipo de músico. Apesar de Camarate exemplificar o caso do aprendizado para o piano, não deixa de mencionar outros músicos. 0 rabequista, o flautista, cornetistas e cantores. Muito provavelmente Camarate se preocupa com a "pianolatria" que

\footnotetext{
${ }^{4}$ Um resumo deste debate pode ser visto em MORILA (2004).
} 
MORILA, Ailton Pereira (2016). Métodos pioneiros de ensino musical no Brasil: críticas, lutas e rivalidades. Per Musi. Ed. por Fausto Borém, Eduardo Rosse e Débora Borburema. Belo Horizonte: UFMG, n.34, p.1-34.

segundo análise posterior de Mário de Andrade, assolava a capital paulista no século XIX. (1975, p.17). CAMARATE (A Música para todos, 1899, p.554) dispara: "Pôe um dia o dedo n'um teclado de piano e fez-se musico amador; o que é muito differente de amador de musica."

A herança material é decisiva aqui para o aprendiz. 0 simples fato da existência do instrumento no seu cotidiano permite-lhe - se não o impele - familiarizar-se com ele. Aprende então a manusear algumas notas ("castigar oito notas") e utilizando-se da memória musical reproduz um lundu ("o lundu, o lundu clássico, que se chama lundu, como se poderia chamar outra cousa"). A primeira canção reproduzida no instrumento é, como deixa claro Camarate, uma canção simples e bastante corrente. Este músico iniciante ouviu e a viu tocar inúmeras vezes, permitindo uma memorização.

Cabe aqui um parêntese sobre a construção melódica das canções populares. As canções populares são transmitidas oralmente e não como partituras. NETTL (1986) indica este como um dos motivos da simplicidade das mesmas. Assim sendo, a simplicidade da linha melódica simplifica o trabalho do músico em decorá-la. De maneira análoga, a simplicidade das canções auxilia o músico iniciante a reproduzila de modo razoável.

Antes destas análises das canções populares que se desenvolveram com o auxílio da antropologia e constituíram um campo específico do saber musicológico - a etnomusicologia - a simplicidade destas era mormente vista como pobreza de composição. Se a linha melódica era simples de ser entendida e memorizada, o arranjo poderia, entretanto, ser modificado livremente pelo executante. Neste sentido, o executante atua também como compositor, pois acrescenta à linha melódica elementos de acordo com sua capacidade e vontade.

Voltando ao músico exemplar de Camarate, este continua a experimentar e experimentar as teclas do piano, sem que mais nada lhe saia do instrumento. Está reduzido a dois acordes. Eis que surge a figura não de um professor, mas de outro músico amador mais adiantado. Este lhe ensina outro acorde, abrindo "um campo 
MORILA, Ailton Pereira (2016). Métodos pioneiros de ensino musical no Brasil: críticas, lutas e rivalidades. Per Musi. Ed. por Fausto Borém, Eduardo Rosse e Débora Borburema. Belo Horizonte: UFMG, n.34, p.1-34.

vastíssimo as suas idéas musicais" como ironicamente escreve. Assim prossegue neste aprendizado entre observações e conselhos, aulas informais e prática. 0 amigo lhe ensina um "tom menor" e abre-lhe o leque. A prática constante melhora sua técnica. Não toca mais somente com o "furabollos", mas o auxiliam "o pai de todos e o seu vizinho" e ao largo de três meses juntam-se "o minimo e o matapiolhos". A prática o leva mais longe. Cria soluções consagradas como o mordente. Evidentemente por não estar familiarizado com a nomenclatura musical o rebatiza de "saca-rolhas". Imitando outro músico, reinventa o "soluço". (A Música para todos, 1899, p.554).

A prática é, portanto, motora deste músico. Àquela primeira melodia juntam se outras. À linha melódica simplesmente reproduzida somam-se a arranjos mais ou menos elaborados. Dependendo das possibilidades, o músico amador se arrisca em composições e notações, e mesmo Camarate dá o braço a torcer: "limita-se a escrever valsas, polkas e quadrilhas, com uma orthografia musical muito fantástica, mas onde fulgem verdadeiros lampejos de talento." (A Música para todos, 1899, p.554). Camarate consegue ainda explicitar uma hierarquia dos músicos amadores. Este músico descrito anteriormente é o "pianista de sol e do" ou "pianista arrebentado". Hierarquicamente superior estaria o "pianista amolador", que difere do primeiro, pois em algum momento entra em contato com uma educação formal, quer seja em esporádicas aulas com um músico profissional, quer seja com algum método ou compêndio de música.

Camarate coloca na categoria de músicos amadores uma legião de músicos que fogem ao popular. Neste caso estaria A.P.S. que em carta enviada à redação d'A Música para todos (1897), se diz amante da música, mas por não dispor de recursos ensina ele mesmo a seus filhos. Nesta categoria estariam também as "senhoras" donas de casa, que em artigo posterior - e mudando o tom - Camarate não deixa de elogiar. Pesando nas críticas ou elogiando algumas categorias de músicos amadores, Camarate cria uma linha divisória. Musicista são os que aprenderam em escolas especializadas e/ou com professores reconhecidos por sua experiência e saber. 0 restante - da "senhora" da casa ao violeiro de rua - são tão somente músicos amadores, ou amoladores. Camarate silencia a respeito do aprendizado musical nas 
MORILA, Ailton Pereira (2016). Métodos pioneiros de ensino musical no Brasil: críticas, lutas e rivalidades. Per Musi. Ed. por Fausto Borém, Eduardo Rosse e Débora Borburema. Belo Horizonte: UFMG, n.34, p.1-34.

escolas, muito provavelmente para evitar uma embaraçosa comparação entre os "cantos aprendidos por audição" pelos alunos e os "aprendidos de ouvido" pelo músico popular. Mas um questionamento permanece: nesta hierarquia musical, onde no topo estariam os músicos profissionais e na base os "músicos de sol e do" onde se enquadrariam os alunos da escola pública? Desta maneira (e somente como efeito colateral), Camarate nos explica pormenorizadamente o método da rua, i.e., o aprendizado musical assistemático, que acontecia no dia-a-dia da cidade.

\section{6 - De volta à escola}

As tentativas de se criar um método único, que servisse tanto ao ensino escolar quanto ao particular se frustraram. A iniciativa de Elias Alvares Lobo não surtira o efeito desejado, como vimos nas críticas. Mesmo na escola, o método de Elias Alvares Lobo rivalizava com o Tonic-solfa e o Galin-Paris-Chevé, lançando os alunos em três convenções diferentes. Luigi Chiaffarelli, um dos mais cultuados professores de então, apesar de publicar o seu próprio método, foi criticado pelos seus pares de maneira efusiva. A questão do método único parecia ter arrefecido. Findo o jornal $A$ musica para todos, diminuídas as discussões musicais n'A Provincia de São Paulo, é a escola, entretanto, e em especial a Revista de Ensino que abre espaço para a questão do ensino musical. Nas páginas da revista que é gestado o último método de ensino musical publicado em São Paulo no final do Império e início do período Republicano.

Evitando as inovações - e as críticas - do método de Elias Alvares LOBO (1875), e também as nomenclaturas diferenciadas do Tonic-solfa e Galin-Paris-Chevé, João Gomes Jr. faz publicar na Revista de Ensino (ano I n.4, 10/1902, p.674-680 e 02/1903 n. 6, p.1094-1100) algumas lições que se transformaram no Curso Theorico e Pratico de Musica Elementar ${ }^{5}$ de sua autoria e de Miguel CARNEIRO JR. (1903).

Se Elias Alvares Lobo buscou adaptar os conceitos musicais a um linguajar mais simples, por vezes renomeando e reconceituando, por vezes comparando-os com

${ }^{5}$ Como observou CATANI (1989, p.131), Os colaboradores da Revista de Ensino "eram, em boa parte autores dos livros didáticos adotados nas escolas públicas". 
MORILA, Ailton Pereira (2016). Métodos pioneiros de ensino musical no Brasil: críticas, lutas e rivalidades. Per Musi. Ed. por Fausto Borém, Eduardo Rosse e Débora Borburema. Belo Horizonte: UFMG, n.34, p.1-34.

outros conhecimentos, Gomes Jr. - muito provavelmente conhecedor das críticas que o método anterior fora alvo - simplesmente simplificou e pragmatizou o ensino musical na escola, sem se aventurar em renomeações e reconceituações. Reproduzindo o ambiente da sala de aula o autor aponta para a prática do ensino. Cria alunos e perguntas fictícias e transcreve os possíveis diálogos. Uma aulamodelo: “- Paulo, vá ao quadro-negro e escreva esta sentença: A música é uma arte. Bem. Quantas palavras tem esta sentença?" (Revista de Ensino, ano I n.4, 10/1902, p.674-680)6. Qual o acolhimento que a obra de João Gomes Jr. e Miguel Carneiro Jr. teve?

A crítica partiu de Guanabarino, do Instituto Nacional de Música do Rio de Janeiro. Neste instituto, a preocupação com o método também se fazia presente. Em relatório escrito para o Ministro da Instrução Pública, Correios e Telégrafos, Leopoldo Miguez, então diretor do referido instituto, pede a "regularização do ensino theorico-elementar da musica em todo o paiz". Vale a pena transcrever um longo trecho:

Não estamos no período do academismo e devemos ter inteira liberdade do ensino; e tanto assim o julgo, que nos programmas da ensino deste estabelecimento que dirijo não são apontados methodos e autores, uma vez que julgo dever este Instituto acompanhar o movimento evolutivo da arte e não póde estar por isso sujeito a fórmas, moldes e methodos antigos.

Parece-me, todavia, que, sendo o Instituto Nacional de Musica o estabelecimento modelo de ensino musical, deviam todas as escolas do paiz, ou pelo menos, como já disso, as da Capital Federal, obedecer ao seu programma e methodo de ensino elementar, uma vez que esse programma é alterado sempre que se apresentam melhores methodos ou systemas mais aperfeiçoados do ensino.

De todos os programmas dos diversos estabelecimentos de educação faz parte do ensino primario da musica e é este o que mais serios cuidados deve merecer do Governo, attenta a insufficiencia da maioria dos compendios adoptados e a opinião controversa dos professores.

Dahi resulta que não podem ser aproveitados de uns para outros estabelecimentos os estudos feitos, por isso que o ensino rudimentar mal dirigido prejudica ao alumno que se dedica ao estudo superior da materia.

Pedindo-vos de novo para a execução das medidas que acabo de apresentar-vos como necessarias todo o vosso empenho....(Relatório do director do Instituto Nacional de Musica, 1891, p.9)

\footnotetext{
${ }^{6}$ Uma análise deste método pode ser vista em MORILA (2004) e JARDIM (2003).
} 
MORILA, Ailton Pereira (2016). Métodos pioneiros de ensino musical no Brasil: críticas, lutas e rivalidades. Per Musi. Ed. por Fausto Borém, Eduardo Rosse e Débora Borburema. Belo Horizonte: UFMG, n.34, p.1-34.

Este trecho do relatório, escrito doze anos antes da obra de Gomes Jr., é revelador das contradições do ensino musical: atenta para a controvérsia entre os professores, a insuficiência dos métodos e compêndios, a não padronização dos métodos, enfim, atenta para o ensino musical "mal dirigido" e seus efeitos negativos nos alunos, principalmente no que tange o ensino primário. A solução, segundo Miguez, era adotar um método criado no Instituto, por este ser a instância maior da música no Brasil. Interessante é que no próprio Instituto - a aceitar sua própria palavra nenhum método é adotado, ficando os professores da casa livre para atuarem. Entretanto o racionalismo e a padronização são essenciais para as outras instâncias do ensino como ele mesmo diz. A primazia da concepção de um método único era, portanto, reinvindicada pelo Instituto Nacional de música há mais de uma década.

Mas voltemos à crítica propriamente dita. Segundo João Gomes Jr., Guanabarino teria dito que o "livro não presta", elencando as falhas: falta de compassos, de claves, de divisões. João Gomes Jr. se defende dizendo que a correta notação musical iria surgindo conforme o desenvolvimento dos alunos, acrescentados passo a passo, do mais simples ao mais elaborado. Responde à crítica anunciando os autores que embasaram seu método: Th.Lajarte e Alex Bisson, Savard, Danhauser, Miguel Cardoso, Leopoldo Miguez, P.Bona. Esperava João Gomes Jr. uma crítica sob o ponto de vista didático, visto que a parte musical era tão simplesmente uma adaptação dos métodos dos teóricos mencionados. Adaptação esta que consistia em ir fornecendo paulatinamente as convenções musicais, de acordo com a evolução do aluno. Notese que entre eles encontra-se o próprio Leopoldo Miguez, diretor do Instituto Nacional de Música. João Gomes Jr. teria dado somente uma "feição pedagógica ao método". Rebate ainda a crítica dizendo que o método deveria ser dado à alunos do 4ํaำ pois que nos primeiros anos o ensino é feito pela prática, pela oitiva. Neste sentido, João Gomes Jr. faz uma diferenciação do ensino praticado nas escolas paulistas, enquanto sutilmente mostra que seu interlocutor desconhece as modernas práticas de ensino: "O ensino em musica, em São Paulo, não é feito pela simples e passiva decoração de regras compendiadas." (Revista de Ensino, ano II n.1, 4/1903, p.5759). Não é, segundo ele, um método inovador em termos musicais, pois que utilizava os autores e métodos musicais em voga na época. Também não pode ser encarado 
MORILA, Ailton Pereira (2016). Métodos pioneiros de ensino musical no Brasil: críticas, lutas e rivalidades. Per Musi. Ed. por Fausto Borém, Eduardo Rosse e Débora Borburema. Belo Horizonte: UFMG, n.34, p.1-34.

como um recorte pedagógico. Sua inovação consistia em reelaborar o ensino musical com base nas premissas pedagógicas vigentes, um curso prático, que pouco a pouco ia inserindo o aluno na notação musical erudita.

Finaliza apontando os que elogiaram seu trabalho: Gomes Cardim, Henrique Ruegger, Antonio Leal, Ernesto Castagnoli e Carlos Guimarães.

\section{7 - Enfim um método de futuro}

As discussões acerca dos métodos não terminaram com este episódio. Carlos Alberto Gomes Cardim proferiu uma conferência intitulada $A$ musica e o canto coral na escola: o ensino da musica pelo methodo analytico, publicada em 1912 pela Escola Normal de São Paulo. Em tom de síntese, procura avaliar o que foi feito até então no ensino musical público paulista e delinear as bases para um método definitivo, um método que colocaria fim às discussões sobre o assunto.

Inicia falando que "a inclusão do ensino da musica nos programmas escolares é cousa muito recente entre nós", inclusão esta devido ao governo republicano que descortinou "novos e vastos horizontes". A influência do velho mundo e dos Estados Unidos é também citada. Aliás, exemplos como a França são elencados. (CARDIM, 1912, p.3).

Retoma - mesmo que sinteticamente - todas as propriedades atribuídas à música, alvo de debates e controvérsias entre os musicistas e educadores musicais do período. Apresenta-as como consenso, e não como fruto de lutas e transformações. A música é uma linguagem. Uma linguagem dos sentimentos. A harmonia dos sons desperta a harmonia moral, a ordem, o acordo e "por conseguinte, a perfeição". 0 ritmo desperta a atividade ordenada e organizada. Para a educação do povo é ela insubstituível, pois ameniza os costumes, civiliza as classes inferiores, alivia-lhes as fadigas, os trabalhos, e proporciona-lhes "um prazer innocente em logar de divertimentos grosseiros e ruinosos" (1912, p.5). Conclui: "Educar, amenizar, civilizar, aliviar fadigas, proporcionar prazer, corrigir vícios, eis a acção humanitária e proveitosa da música". (1912, p.5). Mais ainda, proporciona à criança a inserção no universo da cultura erudita, pois "cultiva o gosto, o amor pelo belo," a estética 
MORILA, Ailton Pereira (2016). Métodos pioneiros de ensino musical no Brasil: críticas, lutas e rivalidades. Per Musi. Ed. por Fausto Borém, Eduardo Rosse e Débora Borburema. Belo Horizonte: UFMG, n.34, p.1-34.

erudita enfim. A música e em especial o ensino de canto têm portanto "uma importância extraordinaria" pelos seus aspectos estéticos, morais e físicos.

Gomes Cardim trata, então, de mostrar o quão defasado está este ensino frente às outras disciplinas escolares. As canções mormente cantadas e executadas nas escolas, diz ele, são ruins, quer seja pela sua estética quer seja pela sua dificuldade, não condizente às possibilidades dos alunos. Exemplifica isto expondo um episódio ocorrido quando Oscar Thompson (então Diretor Geral da Instrução Pública) pediu a Ruy de Paula Souza (então Diretor da Escola Normal) que nomeasse uma comissão para escolha dos cantos escolares executados na escola. 0 resultado: muitas canções encontradas e poucas selecionadas. Além disso, as canções estariam sendo gritadas e não cantadas e o método empregado para o ensino seria o mesmo dos tempos do Império. (CARDIM, 1912, p.8). Feita esta explanação, Gomes CARDIM (1912, p.12) se propõe a explicar seu novo método, falando como um pedagogo e não como músico. Afirma que com qualquer método e qualquer processo se aprende: "Mas o papel do educador é procurar dentre os methodos e processos conhecidos qual o que apresenta maiores vantagens, tendo em vista, principalmente, o desenvolvimento das faculdades mentaes." Propõe o método analítico, que descreve com as seguintes palavras:

\begin{abstract}
Encarando a questão sob o ponto de vista pedagogico, temos a dizer que o methodo analytico, o methodo em que se parte do geral para o particular, das consequencias para os principios, dos effeitos para as causas e, exactamente, o que applicamos no nosso ensino. (1912, p.12).
\end{abstract}

A partir deste ponto, explica sucintamente o método, fazendo sempre uma analogia com o ensino da linguagem e embasando-se nos preceitos mais modernos da ciência da época. Rechaça os métodos Galin-Paris-Chevé e o Tonic-solfa por trazerem mais complicações do que soluções, levando ao aluno "duas convenções para uma unica cousa"7. Prefere o que chama de convenção natural, i.e., o uso de Dó, Ré, Mi etc. (1912, p.16). Termina dizendo não saber o destino de tal método, mas que o fez à serviço do ensino.

\footnotetext{
${ }^{7}$ O método Gallin-Paris-Chevé designa Dó por 1, Ré por 2 enquanto que o Tonic-solfa designa Dó por d, Ré por r, e assim por diante.
} 
MORILA, Ailton Pereira (2016). Métodos pioneiros de ensino musical no Brasil: críticas, lutas e rivalidades. Per Musi. Ed. por Fausto Borém, Eduardo Rosse e Débora Borburema. Belo Horizonte: UFMG, n.34, p.1-34.

Sabemos, entretanto o futuro deste método. A conferência realizada foi fruto de suas iniciativas em educação musical no Espírito Santo - onde foi convidado para realizar a reforma de ensino. Depois da palestra e com o auxílio de João Gomes Jr., Cardim publicou o referido método com o título de 0 Ensino da musica pelo methodo analytico em 1914.

A rigor, o que foi apresentado na conferência está exposto de forma mais detalhada no método. Também a prática está melhor delineada, dividida por lições e constando melodias que deveriam ser executadas, evitando assim a utilização pelo professor de melodias consideradas impróprias. ${ }^{8}$

O método analítico de Gomes Cardim e João Gomes Jr. obteve mais sucesso que os anteriores a julgar pela vida longa que teve (em 1929 contava com sua sexta edição). Poucas edições se compararmos com o método de Rafael Coelho Machado que atingiu 40 edições. Se pensarmos, entretanto, no ensino musical escolar e nos efêmeros métodos de Elias Alvares Lobo, do Gallin-Paris-Chevé e do Tonic-solfa, este método teve uma vida longa. As inúmeras discussões, as várias proposições, os vários métodos que se sucederam rapidamente ao longo das décadas finais do século XIX pareciam ter chegado a um termo com este método. Ao menos para a cultura escolar. Em um esforço de síntese, vejamos agora quais as semelhanças e as diferenças entre os diversos métodos apresentados.

\section{8 - Dissonâncias e consonâncias na busca de um método perfeito e único}

Em 4 de dezembro de 1878 Antonio Zeferino Candido escreve na seção "Instrucção publica" do periódico A Provincia de São Paulo sobre o método João de Deus. "0 pensamento humano transmitte-se pela linguagem" diz ele, seja pela escrita ou falada. Continua:

Ambas estas linguagens se aprendem; o homem nasce com aptidões que a educação desenvolve e converte em instrumentos

\footnotetext{
${ }^{8}$ Uma análise do método pode ser encontrada em MORILA (2004).
} 
MORILA, Ailton Pereira (2016). Métodos pioneiros de ensino musical no Brasil: críticas, lutas e rivalidades. Per Musi. Ed. por Fausto Borém, Eduardo Rosse e Débora Borburema. Belo Horizonte: UFMG, n.34, p.1-34.

de trabalho. (A Provincia de São Paulo, 4/12/1878, p.1) [grifos meus]

Na seqüência do artigo, expõe a maneira como se aprende uma e outra (a linguagem falada e a escrita) e suas diferenciações. Expõe o aparelho fonador, explica como o mesmo funciona e vê uma analogia com a música. 0 aparelho fonador é como um instrumento musical, como um órgão. Os pulmões são o fole, as cordas vocais suas palhetas e a boca o seu teclado. Não para por aí a analogia:

E effectivamente, quanto mais formos progredindo nesta analyse interessante, mais analogias encontramos que justificam a similhança das duas artes - a leitura e a musica.

João de Deus disse-me uma vez que o seu methodo era todo musical; cada dia acho mais apropriado o qualificativo. (A Provincia de São Paulo, 4/12/1878, p.1)

Deixando por um momento esta comparação, vemos enunciado neste artigo um princípio que nortearia o ensino do período. As linguagens se aprendem, mais do que se ensinam. Assim, Caetano de Campos profetiza em discurso de 1890:

Nem basta ensinar: é preciso saber ensinar. (...)

Sim, como se aprende! É este o titulo de bemerencia do mestreescola hodierno. A cultura intensiva do espírito, o aproveitamento de todos os detalhes, cada cousa em cada hora, o alimento intellectual o mais completo, dado na proporção da receptividade psychologica, - eis o merito indiscutivel do ensino moderno. (citado por RODRIGUES, 1930, p.233)

No trecho do discurso, Caetano de Campos nomeia quem são os grandes pedagogos que devemos ter em mente: Pestalozzi e Froebel. Rodrigues enfatiza a educação de Pestalozzi:

A actividade é uma lei da puericia, diz Pestalozzi, acostumae as crianças a produzir, educae a mão. Cultivae as faculdades em sua ordem natural. Formae primeiro o espirito para instruil-o depois é outro dos seus aphorismos.

Cultivae primeiro os sentimentos e nunca ensineis a um menino o que elle póde descobrir por si mesmo. Desenvolve a idéa, dae depois a expressão.

É com taes leis sempre presentes ao espirito do mestre, sem o descuido de um só instante, que a creança, graças á sua natural actividade, torna-se productiva em vez de vadia, amiga da verdade e induzida a procural-a por habito, porque tudo o que sabe deve ao 
seu proprio esforço, muito apta para a conquista das noções, porque aperfeiçoaram-lhe os sentidos e com elles a acquisição das idéas finalmente, a criança assim conduzida torna-se habil e fecunda, porque só se lhe deu o que ella podia recceber; porque o que se lhe deu tinha a medida na sua propria psychologia, e tudo o que adquiriu estava baseado na formação do seu caracter, na justiça das coisas e portanto na moral pratica, que é sempre assimilável. A escola em que se aprende a ensinar assim é necessariamente uma escola pratica e longa. (RODRIGUES, 1930, p.198)

0 ensino até então praticado, a importância dada à memorização, a repetição, deveria ser abandonado por ser ultrapassado. (RODRIGUES, 1930, p.246). Entrava em cena o método intuitivo, assim chamado por preocupar-se com a intuição, com a observação. Observar as coisas, os objetos, a natureza, os fenômenos. Educar os sentidos era a prioridade. (FARIA Filho, 2000, p.143) Conhecido também por "lição de coisas" o método apelava para a observação, para a experiência concreta, para a curiosidade infantil. SOUZA (1996, p.144-145) descreve melhor o processo intuitivo:

Tal método surgido na Alemanha no final do século XVIII pela iniciativa de Basedow, Campe e sobretudo de Pestalozzi, foi tributário, por sua vez, das idéias de filósofos e pedagogos como Bacon, Locke, Hume, Rousseau, Rabelais, Comenius, Froebel, entre outros. Consistia na valorização da intuição como fundamento de todo o conhecimento, isto é, a compreensão de que a aquisição dos conhecimentos decorria dos sentidos e da observação. Pestalozzi recomendava a necessidade de psicologizar o ensino adaptando-o ao funcionamento do espírito infantil. Isto significava partir de outros princípios diferentes da lógica predominante no 'método tradicional' de ensino, o qual pautava-se na aprendizagem com base na memória e na repetição consistindo em uma abordagem dedutiva do saber: ir do simples ao complexo ou do geral para o particular.

O método intuitivo, ao contrário, pressupunha uma abordagem indutiva pela qual o ensino deveria partir do particular para o geral, do conhecido para o desconhecido, do concreto para o abstrato. A prática do ensino concreto seria realizada pelas lições de coisas forma pela qual foi vulgarizado. Recebeu, ainda, outras denominações como ensino por aspectos e ensino intuitivo. Segundo Pestalozzi os princípios estabelecidos para as lições de coisas compreendiam: cultivar as faculdades na ordem natural de seu desenvolvimento; começar por conseguinte pelos sentidos; não dizer nada à criança que ela pudesse descobrir por si mesma. Reduzir cada matéria a seus elementos mais simples. Explicar uma dificuldade de cada vez; seguir passo a passo a informação de acordo com o que a criança pudesse receber; atribuir a cada lição um objetivo determinado, imediato ou próximo; desenvolver a idéia e não a palavra; aperfeiçoar a linguagem; proceder do conhecido para o desconhecido; do simples para o composto; da síntese para a análise, seguindo não a ordem do sujeito mas a da natureza. 
MORILA, Ailton Pereira (2016). Métodos pioneiros de ensino musical no Brasil: críticas, lutas e rivalidades. Per Musi. Ed. por Fausto Borém, Eduardo Rosse e Débora Borburema. Belo Horizonte: UFMG, n.34, p.1-34.

Mais do que isso, o ensino deveria ser concêntrico e seriado, partindo do pressuposto que o espírito infantil "vai sem cessar desenvolvendo-se e aumentando intensidade à medida que se acrescentam as forças psíquicas, intelectuais e morais." Dividido em séries, o ensino era cumulativo, i.e., ao passar de uma série a outra o aluno já teria um mínimo de aprendizado que garantiria a base para a maior complexidade da série posterior. (SOUZA, 1996, p.168-169). Tais princípios deveriam nortear a prática pedagógica dos professores, bem como nortear como um todo o processo educativo. Exigia-se, portanto racionalidade, reprodutibilidade. A inexistência destes requisitos por parte de um professor apenas invalidaria a prática de todos os demais. A seriação ficaria comprometida. É neste sentido que a racionalidade dos programas ganha força como vimos. É também neste sentido que o método suplanta as particularidades do ensino de cada professor, como bem salientou SOUZA (1996, p.143-144):

\begin{abstract}
A confiança no método fazia parte da mentalidade do século XIX, impregnada dos princípios de racionalização da produção e da vida social. 0 método era um guia, o caminho seguro para alcançar objetivos e metas estabelecidas. Entende-se, assim, como tal elaboração atinge o campo educacional precisamente no momento em que era forçosa a racionalização dos sistemas educativos com a difusão da escolarização em massa.
\end{abstract}

A individuação dos métodos de ensino era visto mesmo como impeditivo da prática educativa como sinaliza o parecer da Comissão designada para avaliar o programa para os grupos escolares de 27/02/1905:

Isto terá por efeito tirar o vago de certas teses um tanto sintéticas do programa geral e suprimir o arbítrio do professor, arbítrio, que dando lugar a interpretações diversas e por vezes até antagonicas, serve de contínuo estorvo à unificação dos métodos de ensino em nossas escolas. (citado por SOUZA, 1996, p.173)

Suprimir o arbítrio dos professores era essencial para o bom andamento do ensino escolar. Supressão do arbítrio, da individuação pelo método, racional, igual, padronizador, eis a tarefa de então.

A produção dos métodos pressupõe entretanto um recorte dos conteúdos, uma seleção, como nos lembra SOUZA (1996, 163-4): 


\begin{abstract}
A análise dos programas da escola primária paulista nas duas primeiras décadas republicanas revela o que era considerado socialmente legítimo a ser ensinado e aprendido pelas crianças. É preciso ver nesse rol de matérias urna seleção no interior da cultura. Uma seleção que transcende os limites configurados das áreas de conhecimento científico. De fato, como assinala Forquin, a educação escolar supõe sempre uma seleção, isto é, a escola transmite elementos da cultura considerados socialmente válidos e legítimos compreendendo conhecimentos, competências, hábitos, formas de expressão, mitos e símbolos: 'o que se ensina é, então, com efeito, menos a cultura do que esta parte ou esta imagem idealizada de cultura que constitui o objeto de uma aprovação social e constitui de qualquer modo sua versão autorizada sua face legítima'.
\end{abstract}

De volta ao nosso objeto, algumas questões se colocam: o que foi selecionado, o que foi omitido, o que foi adotado e o que foi adaptado nos métodos de ensino musical para a escola? Retomemos o método proposto por João Gomes Jr. e Carneiro Jr. Segundo ele, as críticas que se fizeram ao seu método eram infundadas, pois não se tratava de um método teórico para os primeiros anos, e sim, uma sistematização teórica após anos de estudo prático. Neste sentido o método por ele proposto está em consonância tanto com a legislação que indicava "Os cantos por audição" nos primeiros anos, bem como com os princípios do método intuitivo que enfatizavam o aprendizado pelos sentidos. Seu método, a legislação e os princípios do método intuitivo estavam em consonância.

O método de Gomes Cardim e João Gomes Jr. é, neste sentido, o supra-sumo dos métodos escolares de educação musical, substituindo os métodos de Elias Alvares Lobo, que como vimos foi criticado em sua face musical (notações e nomenclaturas diferentes do padrão) e pedagógica (a utilização do diálogo ao invés do método intuitivo, as comparações simplistas), e o Tonic-solfa e Galin-Paris-Chevé, que trazia convenções diferentes da padronização erudita.

Já na conferência, Gomes Cardim alerta para a necessidade de padronização dos métodos: "não é possível admitir que a base do ensino, o methodo, possa variar com cada uma das disciplinas." (1912, p.13) Se a música é uma linguagem, nada mais improfícuo que adotar métodos diferenciados para o ensino musical. Urgia uma padronização. Padronização esta - que se de início deixou os professores de música 
MORILA, Ailton Pereira (2016). Métodos pioneiros de ensino musical no Brasil: críticas, lutas e rivalidades. Per Musi. Ed. por Fausto Borém, Eduardo Rosse e Débora Borburema. Belo Horizonte: UFMG, n.34, p.1-34.

aturdidos ${ }^{9}$ - venceu pelo embasamento científico-pedagógico, quase inconteste na época. Vencem também os cantos apreendidos por audição nos dois primeiros anos do ensino preliminar. Só a partir dai o aluno teria capacidade para intuir a teoria.

E se comparamos este método com o "método da rua", i.e., a aprendizagem assistemática dos músicos amadores? As semelhanças são notáveis. Assim como a criança deveria aprender com a observação e o uso dos sentidos, em especial a audição, o músico amador aprendia, segundo Camarate, vendo e ouvindo um determinado músico tocar, e reproduzindo a seu próprio modo o que tinha aprendido. Da mesma maneira a criança deveria ir galgando na prática os subsídios para o aprendizado musical. As diferenças são, entretanto maiores que as semelhanças. Enquanto o músico amador é sujeito do processo, sendo auxiliado por outrem conforme sua conveniência, a criança deste cedo é amparada pelo professor. É este quem escolhe o repertório musical, de acordo com seus conhecimentos e de acordo com a evolução da criança. Inicia-se por canções simples que pouco a pouco se tornam complexas. 0 que porventura a criança gostaria de cantar seria deixado de lado frente ao conhecimento e experiência do professor. A diferença não pára por aí. Após este aprendizado dos sentidos, a sistematização - leia-se, a notação erudita da música - se faz presente. Enquanto o músico amador continua seu aprendizado de "ouvido", a criança em determinado momento vai, sempre com o auxílio do professor, sistematizar, teorizar, racionalizar e aprender a correta notação e teoria musical. Como observou JARDIM (2003, p.80), "A teoria deveria ser deduzida, $a$ posteriori, pela prática musical."

Destas diferenças advêm duas importantes questões: a escolha do repertório e a notação musical. A escolha por parte do professor do repertório musical e ainda da publicação deste repertório nas revistas educacionais do período, deixa de fora as canções típicas do cancioneiro popular. Assim, se o músico amador começa com o lundu, a criança começa com "A entrada do jardim". Como a seleção parte do professor e este detém o saber técnico, a não-escolha das canções populares tem o

\footnotetext{
${ }^{9}$ Exemplos disto são os professores Antonio A.Sierra no Espírito Santo e Antonio Candido Guimarães em São Paulo. O plano, segundo CARDIM "foi recebido com muito interesse mas com a mais cabal descrença" por Antonio A.Sierra. Já Antonio Candido Guimarães "relutando a princípio, em applicar o nosso processo, por achal-o, absurdo, tornou-se, depois, em vista dos resultados obtidos, o seu maior propagandista." (1926, p.30).
} 
MORILA, Ailton Pereira (2016). Métodos pioneiros de ensino musical no Brasil: críticas, lutas e rivalidades. Per Musi. Ed. por Fausto Borém, Eduardo Rosse e Débora Borburema. Belo Horizonte: UFMG, n.34, p.1-34.

efeito de desvalorizá-las, frente às canções escolares, estas sim modelos de aprendizado.

Mas vimos que a crítica às canções escolares era grande. A qualidade estética e o grau de dificuldade eram questionados. Segundo Cardim, poucas puderam ser selecionadas por uma comissão especialmente designada para isto. Frente a esta questão, aliada à da necessidade de iniciar o ensino com melodias simples e conhecidas, uma dúvida permanece: a não utilização de melodias populares. Teria sido a questão estética o principal empecilho? Nenhuma música do cancioneiro popular - que era vastíssimo - agradava os professores? Vimos que não. Mesmo no mais ferrenho artigo sobre os músicos populares, Camarate admite a existência de "boas" composições. Além disso, não podemos esquecer o esforço de Sílvio Romero em recolher cantos e canções populares. Romero era muito proeminente e seu trabalho por demais visível para ser ignorado, mas foi. 0 fator estético não foi, portanto, o motivo da não inclusão.

Gomes CARDIM (1912, p.9) foi a única voz dissonante ao propor a utilização de músicas populares no ensino. Em sua conferência, pergunta aos seus pares: "Por que não podemos ter a nossa escola, oriunda das nossas belas canções populares?" Devemos procurar a resposta não no valor estético das canções populares, mas no âmbito social e político. Mesmo CARDIM (1912, p.21) se contradiz na conferência ao falar da inspiração e arte: “É, exactamente, contra a inspiração sem arte que nós nos devemos insurgir. 0 sentimento repelle a arte sem inspiração; é necessario que a educação musical repilla a inspiração sem arte". Como aceitar a canção popular, mesmo que "inspirada" se esta não corresponde aos cânones da arte?

Além disso, seria tarefa difícil levar a canção popular para a escola sem que com isso se trouxesse toda uma cultura popular que a ela estava intimamente imbricada e que se queria tanto moldar e transformar. Talvez por isso é que no método organizado com João Gomes Jr. a questão da canção popular tenha sido posta de lado por Cardim. Mesmo assim, ele lançou as bases da utilização da canção popular nas escolas, que seria efetivada nas décadas seguintes. Dentre as canções populares, segundo Cardim, deveriam ser selecionadas as mais "innocentes" (1912, p.11), ou 
MORILA, Ailton Pereira (2016). Métodos pioneiros de ensino musical no Brasil: críticas, lutas e rivalidades. Per Musi. Ed. por Fausto Borém, Eduardo Rosse e Débora Borburema. Belo Horizonte: UFMG, n.34, p.1-34.

seja, as que menos ligações tivessem com o concreto. Feita esta seleção, haveria a necessidade de "moldal-a", i.e., transformá-la no padrão estético aceitável. Ainda assim, e conforme esquema proposto por ele, as canções populares nacionais estariam presentes no início do ensino, sendo pouco a pouco substituídas por músicas mais eruditas, criando assim uma hierarquia onde a canção popular comporia a base da pirâmide. No topo estariam Mozart, Beethoven, Wagner, Chopin etc. Selecionar e "corrigir", por assim dizer, a letra e melodia popular retirando-a de seu contexto, com o intuito de facilitar o início do ensino musical. Modificada, descontextualizada, “congelada”, esta canção passa a fazer parte do folclore e não mais da cultura popular. Podemos mesmo cunhar um termo para este processo: folclorização.

Verifica-se uma cisão: de um lado a canção popular e cultura popular. De outro o folclore e as canções folclóricas. A linha divisória pode ser tênue, mas é identificável. Além das "correções", o uso, a função da canção é o principal indicativo. Ao invés de ensinar valores e normas - como na cultura popular - a canção folclórica é curiosidade, "peça de museu" utilizada para o início do ensino musical. Este processo se deu, como já foi dito, em anos subseqüentes, mas suas bases já estavam sendo postas.

Não devemos, entretanto confundir esta folclorização com a ressignificação ou contrafação comum no período estudado. A contrafação ou ressignificação é uma transformação completa do motivo popular (letra e melodia) para uso na escola. Assume, freqüentemente, a forma de uma paródia. Tal é a modificação que, por vezes, não conseguimos nem descobrir qual foi a canção ou canções populares que a inspiraram ${ }^{10}$.

GILIOLI (2003) aponta como comum na República a utilização de canções folclóricas. Devemos insistir, no entanto, que não há indicações do uso de canções populares na escola entre 1890 e 1910, e que a folclorização tal qual definida é, portanto, posterior a 1912, sendo a contrafação comum nas duas primeiras décadas republicanas.

\footnotetext{
${ }^{10}$ Para a ressignificação de canções populares ver MORILA (1999; 2004).
} 
MORILA, Ailton Pereira (2016). Métodos pioneiros de ensino musical no Brasil: críticas, lutas e rivalidades. Per Musi. Ed. por Fausto Borém, Eduardo Rosse e Débora Borburema. Belo Horizonte: UFMG, n.34, p.1-34.

As colocações de Cardim revelam outros pontos interessantes. Gomes Cardim propõe à educação musical escolar, portanto, "repelir a inspiração sem arte", dai a preocupação com o repertório. Como ele mesmo apontou, a música erudita segue outra orientação: "repelle a arte sem inspiração" (1912, p.21). Esta orientação, como é sabido, vai buscar nas músicas populares sua fonte de inspiração nas décadas seguintes, a exemplo do acontecido em outros países e a exemplo do que fizeram Alexandre Levy e Alberto Nepomucemo (ANDRADE, 1975, p.30) e que Chiaffarelli apontava como futuro musical. A cultura erudita vai utilizar a cultura popular como fonte de inspiração. A cultura escolar entretanto vai resignificá-la (até 1910) para depois folclorizá-la (após 1912).

A segunda questão que advém das diferenças entre os métodos é a notação musical. A entrada da criança na notação erudita a afasta também da música popular, transmitida oralmente. A preocupação com a correta notação musical atinge níveis maiores que a utilizada por músicos eruditos. Está marcada a diferenciação entre música popular e música erudita, e mais ainda entre oralidade e escrita. JARDIM (2003, p.36) explica: "Ler a partitura musical era participar da vida social e tal conhecimento estava sendo, nesse momento, difundido dentro da escola".

Se inicialmente o aprendizado musical escolar era similar ao aprendizado musical popular (de ouvido), a partir do $3^{\circ}$ ano da escola preliminar um "divisor de águas" era criado. A notação musical ocidental separava definitivamente a cultura escolar da cultura popular. Esta questão era premente. Em seu método CARDIM (1926, p.15) ressalta a preocupação de que alguns alunos ao invés de estarem lendo a partitura, as tinham guardado na memória (aprendizado típico da cultura popular), e assim a reproduziam tão logo ouvissem as primeiras notas. Daí a importância de se colocarem canções desconhecidas ao longo do ensino. A divisão social estava feita, de um lado as pessoas que dominavam o código escrito e com ele a notação musical, de outro os incultos, os ignóbeis que não a dominavam. LAHIRE (1993) aborda bem esta questão. A crescente valoração da escrita e da escolarização impõe novas formas de dominação, ou melhor, recompõem as relações de dominação e poder. Ao mesmo tempo legitimam o poder daqueles que a dominam, geram a "produção da 
MORILA, Ailton Pereira (2016). Métodos pioneiros de ensino musical no Brasil: críticas, lutas e rivalidades. Per Musi. Ed. por Fausto Borém, Eduardo Rosse e Débora Borburema. Belo Horizonte: UFMG, n.34, p.1-34.

ignorância, da selvageria interior". 0 povo, destituído deste saber - passa a ser encarado como "algo a educar."

Lembremos que a principal crítica aos métodos de Elias Alvares Lobo é a notação musical. No intuito de simplificar, Lobo renomeia os jargões musicais, aproximando perigosamente do saber popular. Vimos que o músico amador nomeia diferentemente posições, andamentos não correspondendo na maior parte das vezes à notação erudita. A grande experiência de Elias Alvares Lobo com a música popular deve ter permitido um meio-termo entre as duas, o que lhe valeu críticas exaltadas. A notação deveria ser erudita, pois do contrário o popular poderia ser valorizado. É neste sentido que o método de Gallin-Paris-Chevé e o Tonic-solfa são refutados. Criar notações não convencionais, com padrões diferentes seria aceitar e colocar em pé de igualdade a existência e a utilização de outras notações, inclusive as notações populares. Exceção, entretanto ao manosolfa, método derivado do Tonic-solfa. Mesmo no método de Cardim ele é utilizado e posteriormente (pós 1930) um livro sobre o manosolfa é publicado11. Apesar de CARDIM (1926, p.24) não considerá-lo como método, aceita a sua utilização. As razões disso podem estar relacionadas ao seu criador: João Gomes Jr. Figura proeminente no ensino musical escolar e companheiro de Gomes Cardim no $O$ ensino da musica pelo methodo analytico, convinha manter o manosolfa, mesmo que perifericamente, como "meio de verificação".

Isto é revelador. As discussões acerca dos métodos e da cultura escolar deixavam por vezes o terreno do pedagógico para entrar nos imbricados meandros das relações sociais e de poder. Sintomaticamente, este desprezo pela canção popular não leva em conta as preocupações nascentes com os estudos folclóricos. Se Sílvio Romero está procurando recolher e sistematizar os contos e canções populares no intuito de conhecer o saber popular, e mais ainda de verificar as confluências entre o saber popular e o saber letrado, a escola, ao menos neste momento, está se afastando deste popular. Desta maneira a escola faz questão de ignorar os estudos folclóricos, deixando mesmo de lado este nascente campo de conhecimento.

\footnotetext{
11 Trata-se de Aulas de mano-solfa, obra approvada pela directoria Geral de Ensino para uso dos alunos das escolas normaes, complementares, Instituto Musical de São Paulo e sociedades orfeônicas. São Paulo: Casa Wagner, 193? de João Gomes Jr.
} 
MORILA, Ailton Pereira (2016). Métodos pioneiros de ensino musical no Brasil: críticas, lutas e rivalidades. Per Musi. Ed. por Fausto Borém, Eduardo Rosse e Débora Borburema. Belo Horizonte: UFMG, n.34, p.1-34.

Enquanto alguns autores e algumas novas idéias científicas são ditas e re-ditas, os estudos folclóricos são silenciados. Mesmo quando não se tinha ainda músicas escolares suficientes para o ensino de música eram preferidas as traduções do alemão e do inglês de canções escolares do que a utilização de canções populares, como se pode verificar na Revista do Jardim da Infância ${ }^{12}$.

E o que dizer do ensino da música erudita? Temos o exemplo de Chiaffarelli, mas este não é o único. Outras obras de cunho musical foram, como vimos, publicadas no período. Aliada a questão da correção técnica e de como ensinar a música, a preocupação histórica é notável. Permeada pelas ideias evolucionistas da época, os autores se debruçaram sobre os rumos da história musical, tanto brasileira quanto mundial. Chiaffarelli coloca estas preocupações como essenciais no ensino musical. Não adianta tocar corretamente determinado compositor, é necessária uma cultura geral, que englobe a vida do compositor, os meios técnicos de execução, o ambiente e a aceitação das peças musicais, enfim a história da música e não só a música. Preocupação demonstrada nos concertos históricos e também nas cadernetas dos seus alunos, como bem observou JUNQUEIRA (1982).

Note-se que as críticas veementes que Chiaffarelli recebeu com relação aos seus concertos históricos diziam respeito à correta utilização do conceito histórico e da palavra concerto. Nenhum dos seus críticos mostrou a necessidade de se suprimir do ensino musical a história da música e dos compositores. Pelo contrário, suas críticas reafirmavam a importância da história. Felix Otero chega mesmo a dizer que ao invés de ensinar história, os concertos de Chiaffarelli poderiam ter o sentido inverso, i.e., confundir os leigos. Daí a importância da correção histórica dos concertos. Os autores discordavam em detalhes, minúcias e até mesmo em conceitos. Mas todos concordavam: a história da música é essencial para o ensino musical.

O que fez a escola com esta noção tão cara aos professores de música da época? Não viu ou não quis ver. Em nenhuma discussão sobre o ensino musical nas escolas a questão de se ensinar a história da música é colocada. Falta de tempo, falta de espaço

${ }^{12}$ Ver MORILA (2002). 
MORILA, Ailton Pereira (2016). Métodos pioneiros de ensino musical no Brasil: críticas, lutas e rivalidades. Per Musi. Ed. por Fausto Borém, Eduardo Rosse e Débora Borburema. Belo Horizonte: UFMG, n.34, p.1-34.

em um programa extremamente abrangente podem ser indicativa desta ausência. Entretanto, jamais foi relativizado, ou melhor, historicizado o conceito de música enquanto uma linguagem historicamente construída. Desta maneira o conhecimento musical torna-se a-histórico, quase que natural, palavra aliás muito utilizada. A notação e a produção musical nesta perspectiva assumem ares de universal e atemporal e não fruto de uma historicidade. 0 conhecimento se reifica. Não é algo construído, mas algo existente, alguns a dominam e outros não.

Posteriormente, a história é colocada no ensino, não com o intuito de historicizar o conhecimento musical, mas com o fito de "construir uma memória histórica" (GILIOLI, 2003, p.164). Mesmo assim esta história é subliminar, transmitida em imagens, como na publicação Hinário Brasileiro de 1922, na qual é apresentado um quadro com as imagens de alguns músicos intitulado "os compositores dos nossos hinos". Se Chiaffarelli e seus interlocutores não viram a história da música ser incorporada aos currículos escolares, Chiaffarelli viu - para agonia de seus críticos - uma metodologia de ensino e de propaganda ser executado com primor pela escola. Criticado pelas suas "maratonas pianísticas" Chiaffarelli nunca fez segredo que um dos objetivos destes concertos era elevar o gosto musical da sociedade, divulgando a música erudita em seus muitos concertos. Também na escola a música e as festas serviram para divulgação. Não da música necessariamente, mas da própria escola. A festa era o momento propício para se fazer ver. As canções, cantadas em coro pelas crianças era o exemplo maior de disciplina, racionalidade e aprendizado. Mais adiante foi incorporada nas festas uma "breve explicação oral" (GILIOLI, 2003, p.190) que precedia as apresentações, bem ao estilo dos concertos de Chiaffarelli. É claro, críticas foram escritas no mesmo sentido que as recebeu Chiaffarelli. Canções difíceis para crianças com poucas noções musicais, ou pior, com ensino musical duvidoso. Mas estas críticas vinham normalmente de entendidos musicais, que quase sempre se mantinham anônimos e circunscritos a seu círculo. É de se supor que o público em geral, desacostumado com as exigências sonoras visse com melhores olhos - e ouvidos - estes espetáculos musicais nas escolas. 0 anonimato em que se fundaram as críticas não deixa dúvidas sobre o valor destas festas para a propaganda escolar e o quão o crítico poderia ser recebido se revelasse seu nome. 
MORILA, Ailton Pereira (2016). Métodos pioneiros de ensino musical no Brasil: críticas, lutas e rivalidades. Per Musi. Ed. por Fausto Borém, Eduardo Rosse e Débora Borburema. Belo Horizonte: UFMG, n.34, p.1-34.

\section{9 - Considerações Finais}

A construção dos saberes escolares da cultura escolar e em especial do ensino musical apresenta semelhanças com a construção do ensino musical erudito e popular, ao mesmo tempo em que apresenta diferenças e omissões. Os objetivos eram outros. Ao músico popular interessava cantar e tocar para um público que junto com ele comporia e recomporia as canções. Sua técnica era seu carisma pessoal. As letras diziam de si e da comunidade que o ouvia. 0 músico erudito deveria mostrar o manejo da técnica, do repertório e do conhecimento musical mais amplo, em suma a erudição, para ser reconhecido como tal. Para a escola a música tinha papéis mais amplos, ao mesmo tempo menos musicais por assim dizer. Ensinar valores, desvalorizar o popular, auxiliar a educação dos sentidos, propagar, propagandear a escola, criar uma cultura mínima em um país supostamente ignorante. As adaptações, omissões e semelhanças dependeram dos objetivos propostos. A cultura escolar - no que tange à educação musical - não surge, portanto do nada. Parte da cultura popular e erudita e participa de algumas discussões destas enquanto silencia outras. Adapta, transforma, aclimata métodos e obras da cultura popular e da cultura erudita ao mesmo tempo em que suprime partes. A cultura escolar vai se constituindo um campo específico sem que com isso torne-se autônoma ou independente. Forma-se mesmo um novo panteão de músicos. Somam-se aos músicos populares e aos músicos eruditos os professores de música escolares, ou melhor, dizendo, os músicos-pedagogos. Outro sentido também pode ser observado. A cultura escolar influencia também a cultura popular e erudita e as transforma. Uma complexa relação dialética pode ser observada entre as culturas.

\section{Referências}

1. A musica para todos: jornal musical. (1896-1899). São Paulo: J.B. D'Arce.

2. A Paulicea: semanário illustrado, crítico e literário. (1896). São Paulo, s/e.

3. A Província de São Paulo. (1875-1889). São Paulo: Typographia d' A Provincia de São Paulo.

4. ANDRADE, M. de. (1975). Aspectos da música brasileira. 2. ed., São Paulo: Martins.

5. CARDIM, C. A. G. (1912). Musica e canto coral na escola: o ensino da musica 
MORILA, Ailton Pereira (2016). Métodos pioneiros de ensino musical no Brasil: críticas, lutas e rivalidades. Per Musi. Ed. por Fausto Borém, Eduardo Rosse e Débora Borburema. Belo Horizonte: UFMG, n.34, p.1-34.

pelo methodo analytico. Conferencia. São Paulo, Siqueira.

6. CARDIM, C. A. G.; GOMES Jr., J. (1926). 0 ensino da musica pelo methodo analytico. Conferencia. 5 ed. [1 ed: 1914]. São Paulo, Siqueira.

7. CHIAFFARELLI, L. (s/i). Migalhas de educação musical. São Paulo: Propriedade reservada.

8. FARIA Filho, L. M. de. (2000). Instrução elementar no século XIX. In: LOPES, E.M. T.; FARIA filho, L. M.; VEIGA, C. G. (org). 500 anos de educação no Brasil. 2 ed. Belo Horizonte: Autêntica.

9. GILIOLI, R. de S. P.(2003). “Civilizando” pela musica: a pedagogia do canto orfeônico na escola paulista da primeira república (1910-1930). Dissertação de mestrado. São Paulo: FE-USP.

10. GONÇALVES, J. (1995). Música na cidade de São Paulo (1850-1900): o circuito da partitura. Dissertação (Mestrado em história) - FFLCH-USP, São Paulo.

11. HILSDORF, M. L. S. (1986). Francisco Rangel Pestana: o educador esquecido. Brasília, INEP/MEC.

12. JUNQUEIRA, F. P.(1982). Escola de música de Luigi Chiaffarelli. Tese (Doutorado) - Mackenzie, São Paulo.

13. LAHIRE, B. (1993). Culture écrite et inégalités scolaires. Lyon: Presses universitaires de Lyon.

14. LOBO, E. A. (1882). Methodo de musica. 2 ed. São Paulo: Jules Martin.

15. MACEDO, E. (1886). Princípios Elementares de musica para uso das escolas de ensino primário de um e outro sexo colligidos segundo o programma official. 2 ed. Porto, Livraria Portuense de Lopes e C $\underline{\text { a }}$.

16. MIGUEZ, L. Relatorio do Intituto Nacional de Musica apresentado ao Dr. João Barbalho Uchoa Cavalcanti, Ministro da Instrucção Publica, Correios e Telegrafos. Rio de Janeiro: Imprenssa Nacional, 1891. Disponível em http://wwwcrl.uchicago.edu/info/brazil/pindex.htm. Acesso em 10/03/2003.

17. MORILA, A. P.(1999). A Escola da rua: cantando a vida na cidade de São Paulo (1870-1910). Vol 1 e 2. Dissertação (Mestrado em Educação) - FEUSP, São Paulo.

18. MORILA, A. P.(2004). Dando o tom: música e cultura nas ruas, salões e escolas da cidade de São Paulo (1870-1906). Tese (Doutorado em Educação) FEUSP, São Paulo.

19. MORILA, A. P.(2002). "Transplantação e aclimatação na Revista do Jardim de Infância (1896-1897)”. Doxa. Revista Paulista de Psicologia e Educação, Araraquara, v. 7, n.1-2, p.35-54. 
MORILA, Ailton Pereira (2016). Métodos pioneiros de ensino musical no Brasil: críticas, lutas e rivalidades. Per Musi. Ed. por Fausto Borém, Eduardo Rosse e Débora Borburema. Belo Horizonte: UFMG, n.34, p.1-34.

20. NETTL, B. Música folklórica y tradicional de los continentes occidentales. Madrid: Alianza Editorial, 1986.

21. O Estado de São Paulo. (1889-1906). São Paulo: Cia. Impressora Paulista.

22. PRESTES, G. (1895). Relatório da Escola Normal Apresentado ao Dr. Alfredo Pujol por Gabriel Prestes. São Paulo.

23. Revista de ensino. (1902-1906). São Paulo: Associação Beneficente do Professorado Público de São Paulo.

24. RODRIGUES, J. L. (1930). Um retrospecto: alguns subsídios para a história pragmática do ensino público em São Paulo. São Paulo: Instituto Ana Rosa.

25. SERGL, M. J. (1991). Elias Alvares Lobo e a música em Itu. Dissertação (Mestrado em Artes) - ECA-USP, São Paulo.

26. SOUZA, R. F. de. (1996). Templos de civilização: um estudo sobre a implantação dos Grupos Escolares no Estado de São Paulo (1890-1910). Tese (Doutorado em Educação) - FEUSP, São Paulo.

Nota sobre o autor

Ailton Pereira Morila é Doutor e mestre em educação pela Faculdade de Educação da Universidade de São Paulo (FEUSP). Graduado em história pela Faculdade de Filosofia, Letras e Ciências Humanas da Universidade de São Paulo (FFLCH-USP). Atualmente é professor adjunto do Departamento de Educação e Ciências Humanas do Centro Universitário Norte do Espírito Santo da Universidade Federal do Espírito Santo (UFES) ministrando aulas para as licenciaturas. Pesquisador do Prometheus - Núcleo de Estudos Críticos. Professor permanente do Programa de Mestrado em Ensino na Educação Básica do CEUNES-UFES onde leciona as disciplinas de História da Cultura e História Social da Arte entre outras. 